MONOPSONY IN MOTION 



\section{MONOPSONY IN MOTION}

IMPERFECT COMPETITION IN

LABOR MARKETS

Alan Manning 
Copyright (C) 2003 by Princeton University Press

Published by Princeton University Press, 41 William Street,

Princeton, New Jersey 08540

In the United Kingdom: Princeton University Press,

3 Market Place, Woodstock, Oxfordshire OX20 1SY

All Rights Reserved

Library of Congress Cataloging-in-Publication Data applied for

ISBN 0-691-11312-2 (alk. paper)

British Library Cataloguing-in-Publication Data

A catalogue record for this book is available from the British Library.

This book has been composed in Sabon

Princeton University Press books are printed on acid-free paper, and meet the guidelines for the permanence and durability of the Committee on Production Guidelines for Book Longevity of the Council on Library Resources

www.pupress.princeton.edu

Printed in the United States of America

10987654321 
To my family 
